\title{
Case Report Warty Carcinoma Penis: An Uncommon Variant
}

\author{
Sushma Thapa, ${ }^{1}$ Arnab Ghosh, ${ }^{1}$ Santosh Shrestha, ${ }^{2}$ Dilasma Ghartimagar, ${ }^{1}$ \\ Raghavan Narasimhan, ${ }^{1}$ and OP Talwar ${ }^{1}$ \\ ${ }^{1}$ Department of Pathology, Manipal College of Medical Sciences, Pokhara, Nepal \\ ${ }^{2}$ Department of Surgery, Western Regional Hospital, Pokhara, Nepal \\ Correspondence should be addressed to Sushma Thapa; sushmathp@hotmail.com
}

Received 25 October 2016; Accepted 18 December 2016; Published 5 January 2017

Academic Editor: Yoji Nagashima

Copyright (C) 2017 Sushma Thapa et al. This is an open access article distributed under the Creative Commons Attribution License, which permits unrestricted use, distribution, and reproduction in any medium, provided the original work is properly cited.

\begin{abstract}
Penile carcinoma frequency varies widely in different parts of the world and comprises 1-10\% of all the malignancies in males. Majority of the cases of penile carcinoma are squamous cell carcinoma of penis comprising $60 \%$ to $70 \%$ of all cases. Warty carcinoma of penis is an unusual neoplasm and a variant of penile squamous cell carcinoma comprising $5 \%-10 \%$ of all the variants. The other histological variants include basaloid, verrucous, papillary, sarcomatous, mixed, and adenosquamous carcinoma. The various histological entities with an exophytic papillary lesions including warty carcinoma are together referred to as the "verruciform" group of neoplasms. The warty carcinoma has to be differentiated from these lesions and is typically distinguished by histological features of hyperkeratosis, arborescent papillomatosis, acanthosis, and prominent koilocytosis with nuclear pleomorphism. We present a case of 65 -year-old male with growth measuring $6 \times 4 \mathrm{~cm}$ in the penis who underwent total penectomy and was diagnosed as warty carcinoma penis.
\end{abstract}

\section{Introduction}

Penile carcinoma frequency varies widely in different parts of the world and comprises $1-10 \%$ of all the malignancies in males [1]. Warty carcinoma (WC) of the penis is an unusual neoplasm and a variant of penile squamous cell (SC) carcinoma [2]. It comprises $5 \%-10 \%$ of all the penile carcinomas [3]. The diagnosis is typically made by histological features of hyperkeratosis, arborescent papillomatosis, acanthosis, and prominent koilocytosis with nuclear pleomorphism [2].

\section{Case Presentation}

A 65-year-old male presented with mass in the penis for 18month duration. It was insidious in onset and gradually progressive. On general examination, the condition of the patient was fair. All the vitals were in stable conditions. There was no palpable inguinal lymphadenopathy. On local examination, there was a large fungating penile mass identified in the glans penis and extending to the shaft of penis. Total penectomy was done and sent for histopathological examination. Grossly, the specimen showed an exophytic, gray white firm mass involving the glans penis and coronal sulcus and extending up to the prepuce and shaft of penis measuring $6 \times 4 \mathrm{~cm}$. The cut surface showed a papillomatous growth (Figure 1). On microscopic examination, the lesion had an arborescent papillomatosis with prominent fibrovascular core (Figure 2). Parakeratosis, acanthosis, and koilocytosis with nuclear pleomorphism were present throughout (Figure 3). The case was reported as WC of the penis with uninvolved surgical margins. On follow-up after 1 year, patient was doing fine and there was no recurrence.

\section{Discussion}

Carcinoma of the penis is rare in developed countries and the frequency is high in Asia (China, Vietnam, Sri Lanka, Burma, and India), Africa (Uganda), and Latin America (Mexico) comprising 10\% of all the malignancies [4]. The etiology is typically multifactorial and includes poor hygiene, lack of circumcision, preexisting condyloma acuminatum, squamous intraepithelial lesions with warty features, and HPV infections [4]. The majority of penile neoplasms are SC, but within this category a heterogeneous variety of growth patterns and histologic subtypes may be seen. The different histological variants include basaloid, verrucous, papillary, 


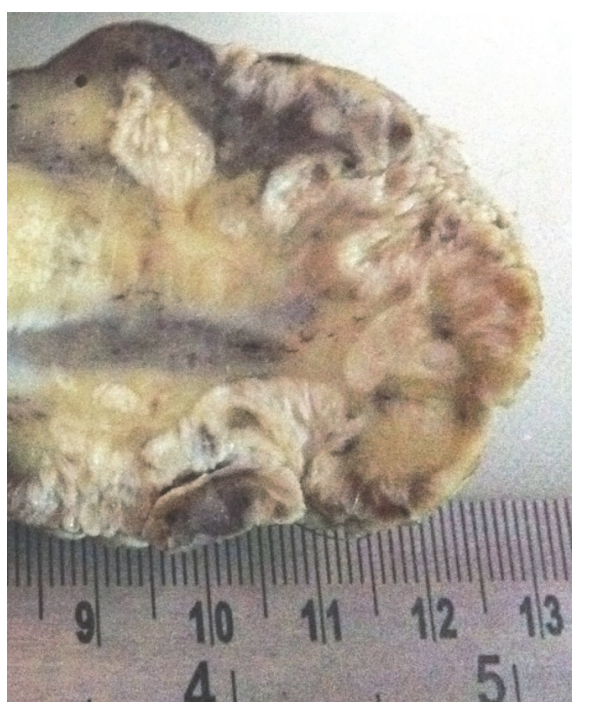

Figure 1: Close-up view of total penectomy specimen showing papillomatous growth.

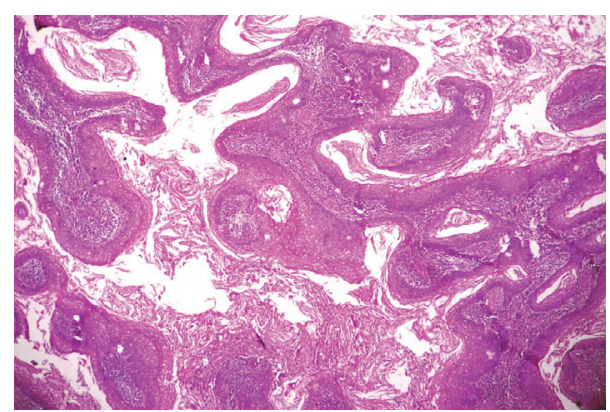

FIGURE 2: Arborizing papillomatosis with parakeratosis and acanthosis $(\mathrm{H} \& \mathrm{E}, \times 100)$.

sarcomatous, mixed, adenosquamous, and warty carcinoma (WC) [2]. WC of the penis is an unusual variant of penile SC comprising only $5 \%-10 \%$ [4]. The first description of WC of the penis in English literature can be found in the article by Davies [5] in 1965 where it has been referred to as malignant condyloma. Similar carcinoma has been described much earlier in the vulva by Rastkar et al. [6] in 1982. The first series of 11 cases of penile WC was published in 2000 by Cubilla et al. [2]. Different authors further found an increased association of human papilloma virus (HPV) infection with vulval as well as penile WC [7-9]. Approximately 40\% of penile cancers have been shown to be attributable to HPV types 16 and 18 . Type 16 has preferentially been associated with a small subset of penile cancers, including basaloid, mixed warty-basaloid, and pure warty carcinomas $[2,10]$. The average age of presentation is 5th decade [11]. Our case presented in 6th decade. In one case series, the patients from the United States were younger than those from Paraguay [2]. The average duration of the disease ranged from 2 to 60 months (average of 19 months) which is similar to our case.

Different histological groups of penile neoplasms with an exophytic papillary lesions including WC are collectively

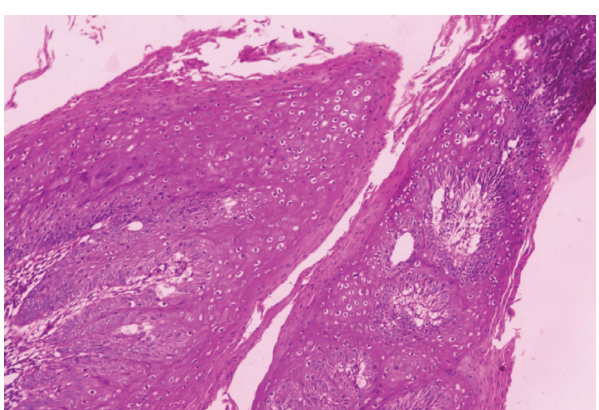

FIGURE 3: Conspicuous koilocytotic atypia present throughout the tumor $(\mathrm{H} \& \mathrm{E}, \times 400)$.

referred to as the "verruciform" group of neoplasms $[2,12]$. Exophytic verruciform lesions of the penis include

(i) condyloma acuminatum;

(ii) giant condyloma acuminatum;

(iii) warty (condylomatous) squamous cell carcinoma;

(iv) warty-basaloid carcinoma;

(v) verrucous carcinoma;

(vi) papillary squamous cell carcinoma, not otherwise specified;

(vii) carcinoma cuniculatum.

Histologically, a papillomatous pattern with acanthosis is noted in all the cases of verruciform lesions and thus they may mimic each other both clinically and on microscopy (Table 1) [2, 10-12]. WC is diagnosed when typical features, namely, papillomatous exophytic growth with rounded papillae, prominent fibrovascular cores, irregular infiltrative tumor interface, and conspicuous koilocytosis, are present. Fibrovascular cores are prominent in WC, papillary carcinoma, not otherwise specified (NOS), and giant condyloma and mostly absent in verrucous carcinoma. Koilocytosis is characterized with clear perinuclear cytoplasmic haloes, wrinkled, enlarged nuclei, bimultinucleated cells, and dyskeratosis [2]. Koilocytic atypia is characteristically seen throughout the tumor in WC and may be seen on the surface in giant condyloma and absent in verrucous and papillary carcinoma, NOS. In verrucous carcinoma, the papillae are regular and the base is characteristically broad and pushing [13]. In papillary carcinoma, NOS, the tip of the papillae is polymorphic, namely, straight, undulated, spiky, rounded, or blunt, and the interface of the tumor and stroma is irregular, but the prominent condylomatous papillae and conspicuous pleomorphic koilocytosis, hallmark of warty tumors, are absent [14]. Warty-basaloid carcinoma also needs to be differentiated from pure WC. It has got 3 histological patterns in which the most common type shows warty growth on the surface and basaloid features in deep infiltrative nest [10]. Carcinoma cuniculatum is characterized by exoendophytic growth with irregular and deep sinuses and tracts connecting the surface of the neoplasms to deep anatomic structures $[11,12]$. 
TABLE 1: Comparison of warty carcinoma and other verruciform lesions.

\begin{tabular}{|c|c|c|c|c|c|c|}
\hline & $\begin{array}{c}\text { Giant } \\
\text { condyloma }\end{array}$ & $\begin{array}{c}\text { Warty } \\
\text { carcinoma }\end{array}$ & $\begin{array}{l}\text { Verrucous } \\
\text { carcinoma }\end{array}$ & $\begin{array}{c}\text { Warty-basaloid } \\
\text { carcinoma }\end{array}$ & $\begin{array}{c}\text { Carcinoma } \\
\text { cuniculatum }\end{array}$ & $\begin{array}{c}\text { Papillary } \\
\text { carcinoma, NOS }\end{array}$ \\
\hline Average size & $>8 \mathrm{~cm}$ & $>5 \mathrm{~cm}$ & $<3.5 \mathrm{~cm}$ & $2-12 \mathrm{~cm}$ & $5-8.9 \mathrm{~cm}$ & $3-14 \mathrm{~cm}$ \\
\hline Papillae & $\begin{array}{c}\text { Arborizing, } \\
\text { nonundulating, } \\
\text { rounded }\end{array}$ & $\begin{array}{l}\text { Long and } \\
\text { undulating, } \\
\text { Arborizing, } \\
\text { rounded, or } \\
\text { tapered }\end{array}$ & Straight & $\begin{array}{l}\text { Similar to warty } \\
\text { carcinoma }\end{array}$ & $\begin{array}{l}\text { Straight or } \\
\text { irregular }\end{array}$ & $\begin{array}{l}\text { Irregular, } \\
\text { complex }\end{array}$ \\
\hline $\begin{array}{l}\text { Fibrovascular } \\
\text { cores }\end{array}$ & Prominent & Prominent & Rare & $\begin{array}{c}\text { Present in } \\
\text { papillomatous } \\
\text { variant }\end{array}$ & Present & Present \\
\hline $\begin{array}{l}\text { Koilocytotic } \\
\text { atypia }\end{array}$ & $\begin{array}{l}\text { Present at } \\
\text { surface }\end{array}$ & $\begin{array}{l}\text { Prominent and } \\
\text { diffuse }\end{array}$ & Absent & $\begin{array}{l}\text { Present on the } \\
\text { surface }\end{array}$ & Absent & Absent \\
\hline Base & $\begin{array}{l}\text { Regular, broad, } \\
\text { and pushing }\end{array}$ & $\begin{array}{l}\text { Rounded or } \\
\text { irregular and } \\
\text { jagged }\end{array}$ & $\begin{array}{l}\text { Regular, broad, } \\
\text { and pushing }\end{array}$ & $\begin{array}{l}\text { Rounded or } \\
\text { irregular and } \\
\text { jagged }\end{array}$ & $\begin{array}{l}\text { Rounded or } \\
\text { irregular and } \\
\text { jagged }\end{array}$ & $\begin{array}{l}\text { Irregular and } \\
\text { jagged }\end{array}$ \\
\hline $\mathrm{HPV}$ & Type 6-12 & Type 16 & Absent & Type 16 & Absent & Absent \\
\hline
\end{tabular}

MRI of the penis to identify invasion into the corpora cavernosa or spongiosum is helpful when the depth and extent of tumor remain unclear on physical examination [4]. Abdominal and pelvic CT or MRI may be useful to exclude metastatic disease. Partial penectomy with a $2 \mathrm{~cm}$ proximal resection margin remains the gold standard treatment [4]. But in our case total penectomy was done due to extension of the tumor into the proximal shaft of the penis. In a study done by Cubilla et al. [15], three prognostic groups of penile $\mathrm{SC}$ were identified in relation to different histologic subtypes and outcome. The verruciform tumors had a better prognosis compared to SC of the usual type which in turn had a better prognosis than the basaloid-sarcomatoid group. Guimarães et al. [16] have documented a $10 \%$ recurrence rate for WC when compared to $28 \%$ for usual SC. Metastatic rate of papillary carcinoma, NOS, is similar to WC and higher than verrucous carcinomas but lower than usual SCs [14]. The incidence of metastasis in warty-basaloid tumors is similar to that of usual SC, higher than WC, and lower than basaloid carcinomas [10].

\section{Conclusion}

Warty carcinoma of penis is an unusual variant of squamous cell carcinoma. The various histological entities with exophytic papillary lesions together known as "verruciform" group of neoplasms of penis should be considered as differential before a definite diagnosis.

\section{Competing Interests}

The authors declare that there is no conflict of interests regarding the publication of this paper.

\section{References}

[1] J. Rosai, Rosai and Ackerman's Surgical Pathology, Mosby Elsevier, New York, NY, USA, 10th edition, 2011.
[2] A. L. Cubilla, E. F. Velazques, V. E. Reuter, E. Oliva, M. C. Mihm Jr., and R. H. Young, "Warty (condylomatous) squamous cell carcinoma of the penis: a report of 11 cases and proposed classification of 'verruciform' penile tumors," The American Journal of Surgical Pathology, vol. 24, no. 4, pp. 505-512, 2000.

[3] R. S. Petersen, A. Isabell, and C. Davis, Eds., Urological Pathology, Lippincott Williams and Wilkins, 2009.

[4] Y. Tarbunou, C. L. Davis, J. Costa, and C. Williams, "Warty condylomatous squamous cell carcinoma of the penis in a 19year-old," Urology Case Reports, vol. 2, no. 3, pp. 79-81, 2014.

[5] S. W. Davies, "Giant condyloma acuminata: incidence among cases diagnosed as carcinoma of the penis," Journal of Clinical Pathology, vol. 18, pp. 142-149, 1965.

[6] G. Rastkar, T. Okagaki, L. B. Twiggs, and B. A. Clark, "Early invasive and in situ warty carcinoma of the valva: clinical, histologic, and electron microscopic study with particular reference to viral association," American Journal of Obstetrics and Gynecology, vol. 143, no. 7, pp. 814-820, 1982.

[7] R. J. Kurman, T. Toki, and M. H. Schiffman, "Basaloid and warty carcinomas of the vulva: distinctive types of squamous cell carcinoma frequently associated with human papillomaviruses," The American Journal of Surgical Pathology, vol. 17, no. 2, pp. 133-145, 1993.

[8] T. Toki, R. J. Kurman, J. S. Park, T. Kessis, R. W. Daniel, and K. V. Shah, "Probable nonpapillomavirus etiology of squamous cell carcinoma of the vulva in older women: a clinicopathologic study using in situ hybridization and polymerase chain reaction," International Journal of Gynecological Pathology, vol. 10, no. 2, pp. 107-125, 1991.

[9] A. L. R. Bezerra, A. Lopes, G. Landman, G. N. Alencar, H. Torloni, and L. L. Villa, "Clinicopathologic features and human papillomavirus DNA prevalence of warty and squamous cell carcinoma of the penis," American Journal of Surgical Pathology, vol. 25, no. 5, pp. 673-678, 2001.

[10] A. Chaux, P. Tamboli, A. Ayala et al., "Warty-basaloid carcinoma: clinicopathological features of a distinctive penile neoplasm. Report of 45 cases," Modern Pathology, vol. 23, no. 6, pp. 896-904, 2010.

[11] H. Moch, P. A. Humphrey, T. M. Ulbright, and V. E. Reuter, "Tumours of penis," in WHO Classification of Tumours of the 
Urinary System and Male Genital. WHO/IARC Classification of Tumours, pp. 269-276, IARC Press, Lyon, France, 4th edition, 2016.

[12] J. E. Barreto, E. F. Velazquez, E. Ayala, J. Torres, and A. L. Cubilla, "Carcinoma cuniculatum: a distinctive variant of penile squamous cell carcinoma-report of 7 cases," American Journal of Surgical Pathology, vol. 31, no. 1, pp. 71-75, 2007.

[13] M. T. Manipadam, S. K. Bhagat, G. Gopalakrishnan, N. S. Kekre, N. K. Chacko, and S. Prasanna, "Warty carcinoma of the penis: a clinicopathological study from South India," Indian Journal of Urology, vol. 29, no. 4, pp. 282-287, 2013.

[14] A. Chaux, F. Soares, I. Rodríguez et al., "Papillary squamous cell carcinoma, Not Otherwise Specified (NOS) of the penis: clinicopathologic features, differential diagnosis, and outcome of 35 cases," American Journal of Surgical Pathology, vol. 34, no. 2, pp. 223-230, 2010.

[15] A. L. Cubilla, V. Reuter, E. Velazquez, A. Piris, S. Saito, and R. H. Young, "Histologic classification of penile carcinoma and its relation to outcome in 61 patients with primary resection," International Journal of Surgical Pathology, vol. 9, no. 2, pp. 111120, 2001.

[16] G. C. Guimarães, I. W. Cunha, F. A. Soares et al., "Penile squamous cell carcinoma clinicopathological features, nodal metastasis and outcome in 333 cases," Journal of Urology, vol. 182, no. 2, pp. 528-534, 2009. 


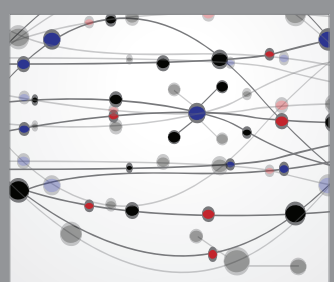

The Scientific World Journal
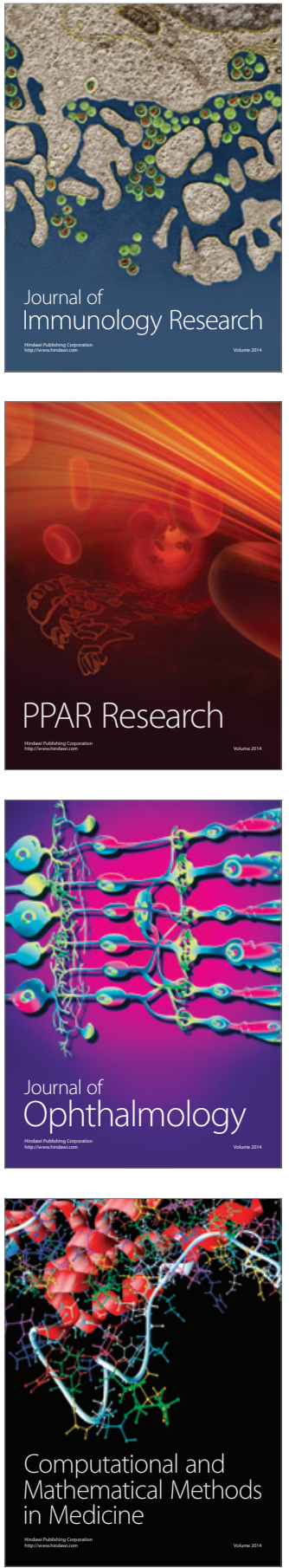

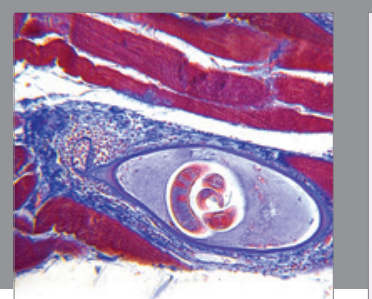

Gastroenterology Research and Practice
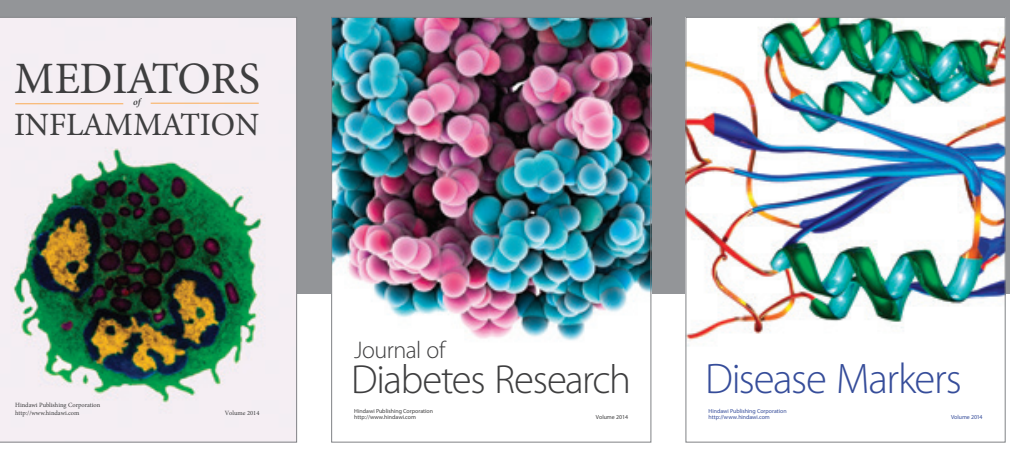

Disease Markers

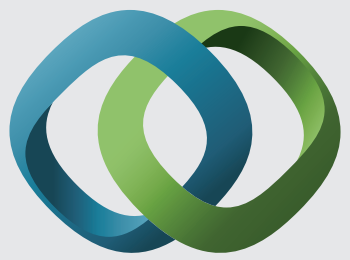

\section{Hindawi}

Submit your manuscripts at

https://www.hindawi.com
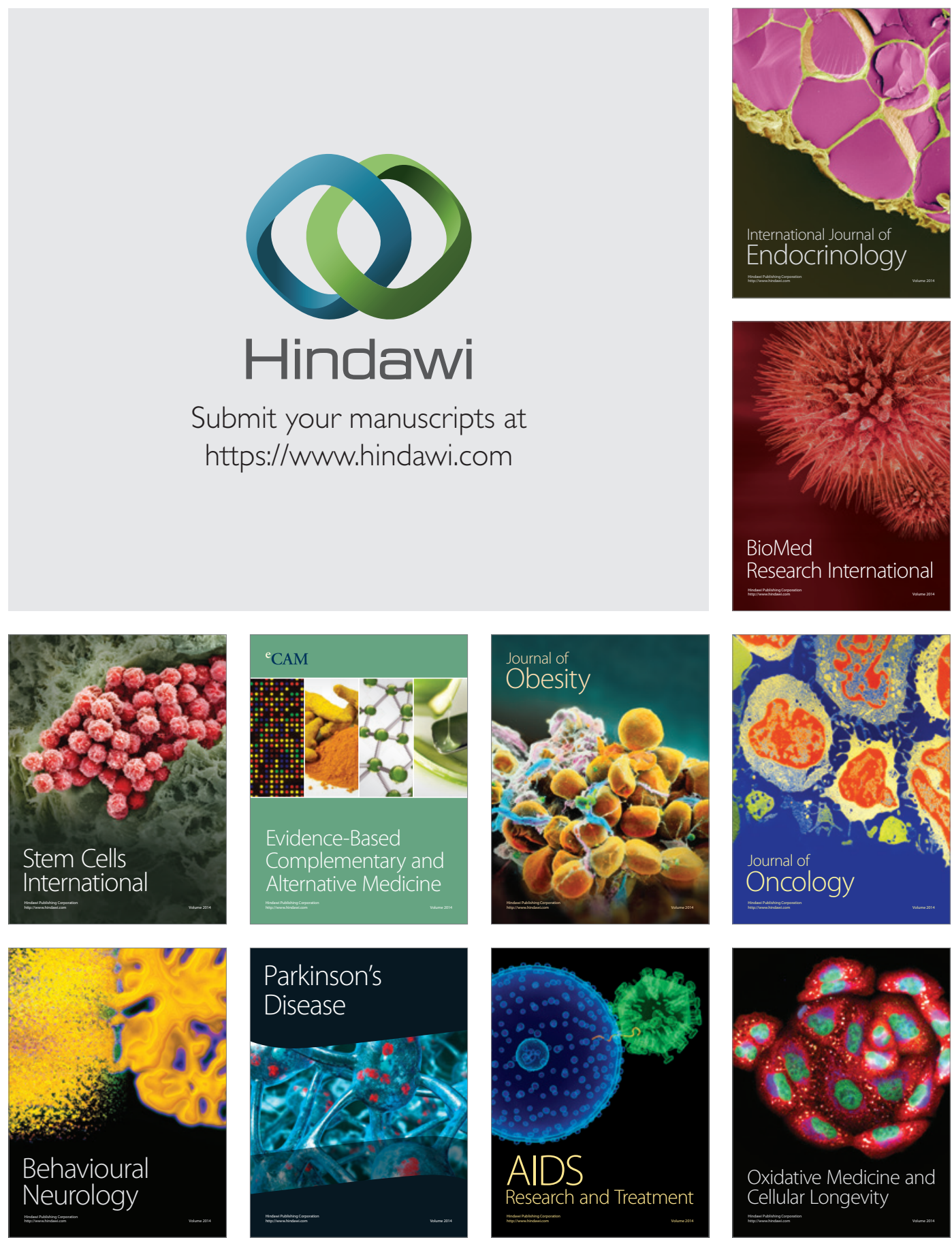